\title{
Puang: A Medium of Blessings in Kinship System of Pakpak Tribe
}

\author{
Yakobus Ndona ${ }^{1}$, Johannes Jefria Gultom ${ }^{2}$ \\ \{yakobusndona@unimed.ac.id ${ }^{1}$,johannes@unimed.ac.id ${ }^{2}$ \} \\ ${ }^{1}$ Pancasila Education and Citizenship Study Program, Faculty of Social Sciences, Universitas Negeri \\ Medan, Jalan Willem Iskandar Pasar V, Medan Estate, Medan, North Sumatera, Indonesia \\ ${ }^{2}$ English Education Study Program, Faculty of Languages and Arts, Universitas Negeri Medan, Jalan \\ Willem Iskandar Pasar V, Medan Estate, Medan, North Sumatera, Indonesia
}

\begin{abstract}
Puang is the main element in the kinship of Pakpak Tribe in North Sumatra Province, which strengthens the family relation, Sukut with prayer and divine blessing. The society puts puang in the highest position in the kinship system of sulangsilima because it represents the origin and points to divinity as the true origin in the maternal line. This paper is based on the results of qualitative research conducted in a field study of "SulangSilima: The Kinship System of Pakpak Tribe and It's Contribution to Strengthening Indonesian Nationalism. The results of a philosophical hermeneutic analysis of the data collected through interviews, observations and documents show that puang is in upstream position, represents divinity as true origin since it becomes a medium of divine blessing. Puang, with such a position, determines the validity of every important decision in the family, Sukut, maintains and strengthens family integrity with prayer and divine blessing. The figure of puang is needed by the nation to maintain the integrity and harmony among the elements of the nation.
\end{abstract}

Keywords: Keywords: puang, a medium of blessings, sulang silima

\section{Introduction}

Pancasila is the principle of national identity, as conveyed by Sukarno, rooted in the culture of the Indonesian tribes since thousands of years ago [1]. Therefore the pattern of 'the existence' of Indonesian people must refer to the wisdom of the national culture which helped to construct Indonesia's identity. Meeting with various wisdom of the nation will find primordial values that underlie the national identity and the existence of Indonesian people. This paper discusses puang, one of the elements in the kinship system of sulang silima in the Pakpak society in North Sumatra, Indonesia, as one of the local pearls of wisdom that for centuries has underpinned the existence, unity, and civilization of the Pakpak people.

Puang occupies a central position in the life of the Pakpak society. Pakpak people put puang as respected, listened, and obeyed party. Besides, this paper was a study on the kinship system of sulang silima from July to September 2019. The study was based on Karl Jaspers's philosophical perspective to examine the Pakpak human existence patterns and the axiological dimensions of sulang silima. The discussion on puang in this paper focuses on three basic issues, namely (1) the nature of puang in the appreciation of the Pakpak society; (2) The existence and role of puang in the philosophical perspective of existence according to Karl Jaspers; and (3) the values in the existence and role of puang in the society. 


\section{Method}

The research was conducted in a qualitative approach. That was based on the need to interpret meaning [2]. The data was collected through interviews, document studies, and participant observation. The collected data was analyzed with a philosophical hermeneutic pattern, namely verstehen, translation, and interpretation. Verstehen was intended to understand the dynamics of life, conversations, documents; translations were used to express ancient languages, ritual spells, and poems. The interpretation was focused on the expression of meanings, both the objective meaning which was placed on the object and the contextual meaning of the present society. Further, the interpretation involved a hermeneutic circle, namely the parts that explains the whole (such as the historical context, cosmological, genealogical, social systems, and metaphysics), and the whole explains the parts [3]. The interpretation also considered reflection to find contextual meaning, and heuristics to place meaning on a broader scope.

\section{Result and discussion}

The term puang, in everyday life of Pakpak society, is often referred to as kula-kula and kalembubu. The term kula-kula is adapted from the Toba Batak language, hula-hula, while the term kalembubu is adapted from the Karonese language. The term puang, as explained by Mansehat Manik (interviewed in the September 22 nd, 2019 ) comes from an older tradition, and refers to the original use of the Pakpak community. The term kula-kula possibly entered Pakpak land together with the arrival of the Toba Batak missionaries who spread the gospel to the Pakpak Bharat region, around 1905.

The use of the term kalembubu can certainly be sourced from assimilation with the Karo population that borders directly with Pakpak district. Many of Pakpak's vocabulary is parallel with Toba Batak and Karonese languages. Many clan names are parallel with Toba, such as Manik, Boang Manalu, Cibro, Purba, and so on. The Pakpak society, in a patrilineal background, knows puang as the mother's family. Puang is the brother(s) of the mother and the parents-in-law. Puang, in a broader context, is also understood as the giver of female ancestors from extended families and clans. The Pakpak society, as told by Mansehat Manik, knows five types of puang, as described in Table 1 below.

Table 1. The Classification of puang in the kinship system of Sulang Silima

\begin{tabular}{clll}
\hline no & types of puang & \multicolumn{1}{c}{ meaning } & \multicolumn{1}{c}{ roles } \\
\hline 1 & $\begin{array}{l}\text { Puangtanoh } \\
2\end{array}$ & $\begin{array}{l}\text { Puangbennaniari } \\
\text { clan of the father's } \\
\text { grandmother } \\
\text { uncles of the father/the } \\
\text { relatives of the } \\
\text { grandmother }\end{array}$ & $\begin{array}{l}\text { In big ceremonies at the level of extended } \\
\text { family, a clan, a village/lebuh } \\
\text { In ceremonies related to the father and his } \\
\text { brothers and the children }\end{array}$ \\
3 & $\begin{array}{l}\text { Puangbenna } \\
\text { Puangpengamaki }\end{array}$ & $\begin{array}{l}\text { Mother's brothers } \\
\text { Clan of parents' in law }\end{array}$ & $\begin{array}{l}\text { In all important moments in life. } \\
\text { In all important moments related to children } \\
\text { and sons/daughters' in law }\end{array}$ \\
5 & Puangpenumpak & $\begin{array}{l}\text { Clan of the wife of the } \\
\text { sons in extended family }\end{array}$ & $\begin{array}{l}\text { In big ceremonies at the level of extended } \\
\text { family, a clan, a village/lebuh }\end{array}$ \\
\hline
\end{tabular}

The classification of puang into five types refers to the five elements of sulang silima. Pakpak society tends to classify things into five parts. The number 'five' for the Pakpak society has an important meaning. Lister Berutu (in an interview on August $8^{\text {th }}, 2019$ ) said that 
five is equal to three, which is an odd number to ensure agreement in deliberations. The researcher sees the number 'five' is not only limited to facilitate the achievement of an agreement but the number 'five' also refers to Jacobs Sumardjo's opinion related to the pattern of the five rice fields [4]. The farmers in the society have a spatial orientation which refers to the upstream as the base, and the downstream as the tip. The main village, which is in the middle acts as the center, then develops to the East and West.

The early ancestors of the Pakpak society, before inhabiting the Pakpak Bharat region, perhaps lived by managing rice fields. Another possibility, the pattern of 'five' comes from the Javanese Hinduism tradition that entered the Pakpak region together with the expansion of the kingdom of Great Majapahit. The use of the term mpu imposed on early ancestors, such as Mри Bada, as told by Sautma Manik (in an interview on September $21^{\text {st }}, 2019$ ) indicates that Pakpak culture also experienced Javanese Hinduism. The pattern of 'five' among the farmers then develops into a kinship system, with puang in the upstream position, berru in downstream, denggan sibeltek (perisang-isang, partulang tengah, and parekur-ekur) in the middle position which widens to the side as shown in Figure 1 below.

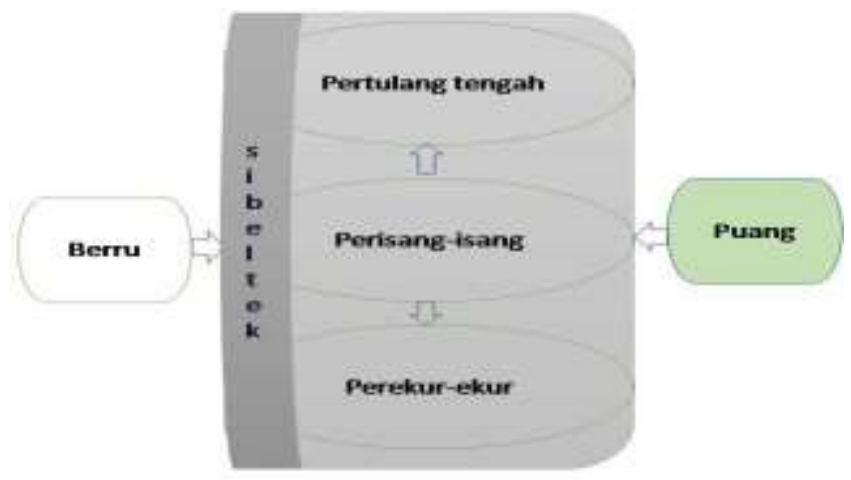

Figure 1. Kinship System with Five Elements

The Pakpak tradition requires all parties to sembah (worship) the Puang. The principle that is always held is kegaben sembah merpuang, which means worshiping puang. The term sembah is also used by the Karonese as well as Toba Bataknese, sombah, with the same meaning. The term sembah in these three sub-tribes is not similar to the word " sembah" in Indonesian which is synonymous with the worship of God [5]. Words of sembah to the Pakpak society, as well as Karonese and Toba Bataknese, are more directed towards respectful attitude, kneeling and obedience.

The use of the word worship may come from ritual practices or acts of worship of the "Divine" in Pakpak's traditional beliefs. Anas Banurea (in the interview 21 September 2019) said that the Pakpak people had a habit of worshiping Mpung Debata Kase-kase, hereinafter abbreviated to Mpung, the ruler of the universe and the source of all life when they wanted to grow crops and harvest agricultural products. The term puang is imposed on the mother and wife giver because of the existence that represents the Mpung. Puang is at the base position which is the origin of mothers giving birth.

The Pakpak community realizes that life originates from the mother, but the mother comes from the puang. Puang, in this position, represents Mpung, the ruler of nature which is the basic origin of all life. Puang, as said by Sakkap Boang Manalu (in the interview on 22 September 2019) is identical to debata na ni idah, the visible God. Puang thus has a divine dimension, which underlies the obligation of worship. Boang Manalu also asserted that 
worship of puang is not because of personal qualities, but because of the nature of divinity. Worship of puang is identical to the worship of Mpung.

Puang as repetition Mpung holds a divine mandate. Sakkap Boang Manalu (in an interview, 27 September 2019) said that the Puang holds the stick of life. The mandate of money appears in the authority to govern the berru, especially concerning adat. The divine mandate requires the parties to obey the money orders. Puang can force the parties to make peace. Puang's advice must be heeded, even when the puang doesn't have adequate personal qualities or disappoints. Puang's advice, for the Pakpak people, is the echo of Mpung's voice, which forbids all forms of resistance. Every form of resistance is believed to be disastrous. The divine mandate assumed is most evident in its role as a medium of blessing (pasu-pasu) for berru. Pakpak people believe that blessing puang is a source of welfare, as illustrated in the following verse.

Butbuten i ruang-ruang, merurusen bulung tebbu, turutens rana puang, simupus kalimbubu, I tangan jari jari lima; Cekep kerina cingkerru buka-buka; Pedalan sulang silima; Enget mersenina, merberru, merkula-kula; Laus mengeluak; Embah karina perlu ula-ula; Gennep gennep suak; Hot mersenina, merberru, merkula-kula.

This poem emphasizes that puang blessing is a source of kegaben (welfare). Berru, if it is difficult to obtain offspring, sons, jobs, fortune can ask for blessings in cash. Thanks to money you can also see it in the words, gab emo ni ulamu, you get your mousen tulusen, which means to love what is done and find what you are looking for; meddas mo measure ndene mi juma mi house, which means hopefully this will be found in the fields and at home; pihir pe berras en, pihir deng ngo tendang kelang or berrungku, which means that even though the rice is hard, even harder the spirit of my daughter-in-law and daughter.

The role of puang as a medium of blessing is most evident in rituals related to the life cycle and various important family events. Mansehat Manik, traditional leader and cultural activist of Pakpak (in the Interview 22 September 2019) tells us that Pakpak people place money as a medium of blessing from the beginning of life. This is evident in the ritual request for children's gifts. Pour benna or peers, while handing a long cloth in the form of a doll conveys words of blessing, en monang, berru, kel, ngggo our spirits bounce to, abing to mo en, hope ndor to merbenna udan in the middle of the family, hope meranak merberru, which means this is berru, we have come, lap here, so you can quickly get a baby. The same pattern occurs at seven months of gestation. Puang while checking for pagit, say words of blessing to expectant mothers, eat this pagit, eat pagit darohmu, which means eat this bitter food, so that your blood becomes bitter to avoid all evil disturbances, and avoid all diseases and distress. Blessings were also conveyed at the first ritual of cutting the baby's hair.

Puang that cuts the baby's hair, chants a prayer mantra using the klembis medium (part of the chicken's backbone), klembis! klembis! stay away from pulian, the softness of the dulpang punggur, the softness of the mo karina mara danger, which means keep away from Surabaya, fallen trees, hit by motor vehicles, struck by lightning, outbreaks of disease and so on. Blessings were also conveyed when berru experienced serious illness. The puang, while giving inhibitory foods or inhibiting food conveys words of blessing, eating food en, ndor nah nuah marsakit, which means eat this to recover from illness and avoid death. The medium of blessing is also displayed in the ritual of entering a new home.

The Puang came with fire and surrounded the new house with fire. Fire in the appreciation of traditional tribes is a symbol of life [6]. The action of the puang carrying and surrounding the new house with fire symbolizes the gift of life blessings to the family of the crew who occupies the new home. Blessings were also conveyed to the berru who had difficulty getting 
a life partner, and the blessing of marriage. Material or wages received in the form of almost all traditional rituals are also related to the role of a medium of blessing. Berru gives ules (traditional cloth) to the puang, identical to the imposition of liturgical or worship clothing to the puang to convey their wishes and requests to the Mpung (Lister Berutu, August 2019). Wages, in addition to ules, often also take the form of gold. Gold, referring to the opinion of Sakkap Boang Manalu (in the interview 22 September 2019) serves as a supporter of puang honor.

Puang, as a representation of Mpung, must love berru. Berru, in the kinship system, sulang silima is indeed at a lower level. This position does not become the basis for the money to treat it as you wish. The lowest position requires puang, who is in a higher position to love. This principle, by the Pakpak community, was formulated in the expression kinibeak elek merberru, which means loving berru. The Toba people, in the kinship system, the pretext of tolu also knows the principle of elek marboru. The Karo community, in the Sulaungun and Simalungun pillars, needs to be demanding also the same principle. This similarity, apart from debates about the origin of genealogy, can be a reference to the linkages of various Batak subtribes in the same source. Kinibeak elek merberru, in short, can be interpreted as loving berru. Love for berru is symbolically depicted in a toast at various traditional celebrations, in the form of hearts and internal organs of sacrificial flesh as a symbol that berru is always in the heart and obtains love from the puang (Sakkap Boang Manalu, in an interview on 22 September 2019).

First, exist in basic origin. The depiction of puang as the face of Mpung Debata Kase-kase, the practice of worshiping puang, and its placement as a medium of blessing, draws Pakpak's human existence concerning origin. Puang is the base, the origin of the mother who gave birth to live. The basic origin of life certainly is not in the money. Puang represents Mpung Debata Kase-kase, Lord of the universe, the basic source of life. This belief is evident in the rituals of land clearing and harvesting agricultural products. The prayer spells at these two rituals go directly to Mpung Debata Kase-kase, who rules the universe and controls the natural cycle. Prayer mantras contain requests for rainfall, soil fertility, pest avoidance. Mpung is subject to a request, because life, including plants, can occur and continue only in connection with the highest divinity [7].

Requests for both rituals, as conveyed by Sautma Manik (in an interview on September 21, 2019), are sometimes directed at the spirits who inhabit the fields. Large trees and stones in the fields are often places to put offerings because they are considered sacred space. The spirits of the inhabitants of the fields, in traditional societies, are believed to represent the presence of the highest divinity in the cosmos, which acts as a medium of communication [8]. The final goal of the request is always directed to the highest divinity, Mpung Debata Kasekase, the Lord of the universe and the basic source of life.

This phenomenon illustrates the appreciation of the Pakpak people that the highest divinity, Mpung, is the foundation of existence. Existence, for humans Pakpak can be achieved only in connection with the Mpung. Special treatment of sacred spaces (big trees, big stones, mountains, etc.) and various ritual practices at these locations illustrate the dependence of human beings on Mpung. Various locations, from the perspective of traditional communities, are the coordinates of the presence of Mpung in the cosmos space [8]. Mircea Eliade said that sacred spaces in traditional cosmology mean exit Mundi that connects humans with the power of the upper world and the power of the underworld [7]. The ritual practice at exit Mundi guarantees the submission of requests to the highest divinity [7].

The question that arises is why the Pakpak community places the puang as a representation of Mpung. Karl Theodore Jaspers said that the human need for communication with the 
highest divinity, Transcendence must deal with infinite distance [9]. Humans cannot be directly related to Transcendence. Transcendence can only be found in chauffer or divine symbols [8]. Humans, because of special characteristics become the main chauffeur [9]. Many traditional communities, with an anthropophilic understanding of divinity, tend to portray human-shaped divinity figures [9]. Pakpak people have the same pattern. Puang, because it is at the base and fatherly-based, is placed as the main chauffeur for Mpung. Puang, certainly not Mpung Debata Kase-kase. Puang is still puang, Mpung remains an infinite distance, but the puang, when placed as a chauffer, symbolizes the presence of Mpung.

Puang, as a chauffeur to the presence of Mpung, takes part in Mpung, although it does not cover the totality of Mpung [10]. Mpung, in Jaspers, is the One, the whole element of divinity [9]. Puang only takes part in certain elements, but still represents and represents the presence of Mpung for berru [11], so that the voice and actions of the puang are lived as Mpung's voice, and the loyalty given is loyalty to Mpung. Placement of puang as a representation of Mpung and a medium of blessing, as well as all forms of respect and loyalty to the puang, shows that Pakpak man places the highest divinity as the foundation of existence. Existence, for humans Pakpak can only be achieved concerning the highest divinity, the Empang, the basic source of life [12].

Second, life as a medium of blessing. The existence and role of money in the Pakpak community inspires people's lives now. The Pakpak community places puang as a representation of Mpung and a medium of blessing for berru. The existence of puang confirms that life must present God's face to others. This confirms that the meaningfulness of life lies in the ability to present God's face to others [13]. Thomas Aquinas said that humans because they obtain the spark of God's life, have noble dignity and dimensions of divinity [14] because it is obliged to present the face of God for others. Humans can present the face of God if it presents goodness to others.

Thomas Aquinas, in Summa Theology, said that God is the perfect good [15]. Humans as the caravan of God in the world must realize God's perfect goodness for others and all beings [15]. Humans can present the goodness of God if they manifest love, peace, and justice [16]. The role of money as a medium of blessing to show shows that God's goodness must first be presented to those below, the weak, suffering and marginalized, which the wise call the little people [17]. The struggle for divine goodness will make life a blessing for others.

\section{Conclusion}

Based on the findings and the discussion, it can be concluded that: First, the identity of the Pakpak community's sulang silima system is worshiped, because it represents the highest divinity and the medium of blessing. The existence of puang is based on the fatherhood and underpins the placement of the puang as the chapter of the Mpung fatherhood, the ruler of the universe and the basic source of life, who is loving and blessing. Placement of puang as a representation and medium thanks to Mpung, along with all forms of respect and loyalty illustrates Pakpak's society believes that existence can only be attained concerning the highest divinity, the base and the basic source of life. This gives inspiration to today's society of the relevance of faith in the struggle for existence, and the obligation to bring good to others and all beings.

\section{References}

[1] Y. Latif, Negara Paripurna. Gramedia Pustaka Utama, 2013.

[2] M. S. Kaelan, "Metode Penelitian Kualitatif Bidang Filsafat," Paradigma. Yogyakarta, 
2005.

[3] F. B. Hardiman, "Seni Memahami: Hermeneutik Dari Schleiermacher sampai Derrida," Yogyakarta: Kanisius, 2015.

[4] J. Sumardjo, "Sunan Ambu STSI Press." Bandung, 2010.

[5] T. R. K. B. Indonesia, "Kamus Bahasa Indonesia," Jakarta Pus. Bhs. Dep. Pendidik. Nas., 2008.

[6] C. W. Buijs, Personal Religion and Magic in Mamasa, West Sulawesi: The search for Powers of Blessing from the Other World of the Gods. Brill, 2016.

[7] M. Eliade, The Sacred and the Profane: The nature of Religion. Houghton Mifflin Harcourt, 1959.

[8] Y. Ndona, Jejak Tuhan di Tanah Keo, Yogyakarta: Keppel, 2019.

[9] K. Jaspers, Philosophy. Chicago and London: The University of Chicago, 1971.

[10] F. W. Dillistone, The Power of Symbols. SCM Press, 1986.

[11] J. Siswanto, "Bereksistensi Dalam Transendensi menurut Pemikiran Karl Jaspers," Diskursus, Vol. 16, no. 2, pp. 158-187, 2017.

[12] Y. Ndona, "Kecenderungan Sentipetal pada Masyarakat Jawawawo-Keo Tengah," 2018.

[13] P. F. Knitter, Menggugat Arogansi Kekristenan. Kanisius, 2005.

[14] L. Leahy, "Horizon Manusia: Dari pengetahuan ke Kebijaksanaan," Yogyakarta: Kanisius, 2002.

[15] W. J. Hankey, "God in Himself: Aquinas' Doctrine of God as Expounded in the Summa Theologiae," 1987.

[16] P. J. XXIII, "Pacem in Terris," 1963.

[17] A. Nolan, Jesus Before Christianity: The Gospel of Liberation. Darton, Longman and Todd, 1977. 